Jpn. J. Pharm. Health Care Sci.

ノート 27(6) 598-604(2001)

\title{
わかりやすい薬剤情報文書の作成と患者からの評価
}

\author{
川端奈緒美*, 西村久雄, 直良浩司, 平野栄作, 岩本喜久生 \\ 島根医科大学医学部附属病院薬剤部†
}

\section{Preparation of Our Intelligible Explanatory Leaflets of Drugs and Questionnaire Survey of Outpatient's Views on them}

\author{
Naomi Kawabata*, Hisao Nishimura, Kohji Naora, Hidenari Hirano and Kikuo Iwamoto \\ Department of Pharmacy, Shimane Medical University Hospital $\uparrow$
}

$\left[\begin{array}{l}\text { Received February 13, } 2001 \\ \text { Accepted October 1, } 2001\end{array}\right]$

To supply drug information using documents is very important to ensure patient safety and the proper use of prescribed drugs. Such documents should include easily understandable information for patients. In the development process of drug information leaflets at our hospital, we incorporated reviews of the documents made by normal individuals and not medical professionals. It was found that more than 100 of descriptions in the documents were given in language that was too technical to be understood by normal individuals. Approximately half of these descriptions were related to "drug effects". We reviewed the information for 500 of 997 drugs using supplementary interpretations and more conventional expressions to make the drug information leaflets more intelligible.

Acceptability of the leaflets by patients was evaluated based on a questionnaire survey to which 300 outpatients responded. As a result, most of the patients reported that the "drug effects" and "initial symptoms of adverse reactions" in the documents were easy to understand by $89 \%$ and $81 \%$ of the patients, respectively.

From these results, our drug information service using more intelligible leaflets was found to effectively promote a better understanding of prescribed drugs, thus leading to their safe and proper use.

Keywords — intelligible explanatory leaflets of drugs, questionnaire survey, safe and proper use of prescribed drugs, normal individuals and not medical professionals, drug information services

\section{緒言}

患者に医薬品を適正に使用してもらうためには，薬剤 情報文書を提供することが必要不可欠となってきてい る。また，その提供は単なる情報の伝達に留まらず，あ くまで情報の受け手である患者が十分に理解できる内容 と表現が用いられていなくてはならない。

患者への薬剤情報提供文書の作成に際しては，患者に わかりやすい文書の表現として，一般向けの薬に関する 書籍等を参考にしたり ${ }^{1)}$, 医師や薬剤師等の医療従事者
が患者にわかりやすいと判断した表現を用いるなどの報 告がある2,3). しかし，患者にわかりやすいかどうかを 実際に確認して提供文書を作成した報告はない。

島根医科大学医学部附属病院（以下, 本院と略す）で は, 患者への薬剂情報提供文書 (以下, 『くすりのせつ めい』と略す）を，新たに医師・薬剤師・看護婦以外の 非医療関係者（以下，非医療関係者と略す）の意見を取 り入れて作成した。この『くすりのせつめい』が，実際 に患者にとってわかりやすい内容であったかどうかを評 価する目的で，外来患者を対象としたアンケートによる 
意識調査を行ったので報告する。

\section{方法}

\section{1. 『くすりのせつめい』の作成}

1 ）原案の作成

『くすりのせつめい』の作成は, 日本病院薬剂師会薬 剂業務委員会からの「患者等への薬剤情報提供の進め方 (答申書) 」) (以下, 答申書と略す) に準じた。今回は, 平成 9 年 7 月より提供している「商品名・成分名」,「く すりの色」，「保管上の注意」等の基本情報の内容に, 「薬の働き」,「一般的な注意」,「初期症状」,「薬価」を 追加した。「薬の働き」は適応をそのまま記載するので はなく, 服薬の必要性に対する理解を深めるため, 可能 な限りその作用も付け加え, 最終的に用語等の整合性を はかった。副作用に関しては，「重大な副作用回避のた めの服薬指導情報集」5-7)等を参考に，患者に気づいてほ しい重大な副作用の初期症状（以下，「初期症状」と略 す）を記載した。また，診療科による使用目的の違いな どを考慮して,「薬の働き」および「初期症状」は診療 科別にシステムへの登録を可能とした。

2 ）医師の意見による修正

薬剂情報文書が医師からみて適切な内容となるよう に，全診療科（18科）の医師（外来医長，病棟医長）に 当該科で使用している医薬品の『くすりのせつめい』の 原案を配布し，加筆・修正を依頼した。

3 ）非医療関係者の意見による修正

薬剤情報文書が非医療関係者からみてもわかりやすい 内容となるように, 当院薬剂部職員の家族 (非医療関係 者）を対象に，わかりにくい表現等の指摘を依頼した。

\section{2. 『くすりのせつめい』に関するアンケート調查}

院内処方せんが出された外来患者を対象としてアン ケートを依頼した。アンケートは自計方式で行い，その 回収には回収箱を用いた。調査期間は作成した『くすり のせつめい』の運用を開始してから約 3 力月後の平成 11 年 5 月17〜19日の 3 日間とした。

\section{結果}

\section{1. 『くすりのせつめい』の作成}

1) 原案の作成

副作用に対する「初期症状」は複数存在する薬品が多 く, 重大な副作用を 2 つ以上有する医薬品では, それぞ れの初期症状が重複するものが多くあった。

患者用には，提供する情報量があまり多くならないよ うに重複する初期症状を可能なかぎり 1 つにまとめた。 さらに初期症状が複数ある場合には, 早期に発現する症
状や患者あるいは家族が気付きやすいと思われる症状を 登録した。

\section{2 ）医師の意見による修正}

当院の全診療科 18 科のうち 11 科では，『くすりのせつ めい』の原案はそのまま承認された. 残り 7 科の医師か ら要望や修正依頼等があり, その件数は延べ38件であっ た。このうち20件について，原案を作成した全997品目 中，335品目 (33.6\%）を医師の意見に基づいて修正し た. 例えばインスリンの「初期症状」のうち単に「冷や 汗がでる」と表現されていた部分が，「時として冷や 汗 ·動悸 ·手足のふるえ等がある（低血糖症状に気づか れた場合はすぐに砂糖などをとって下さい, それでも症 状が良くならない場合はすぐに主治医に受診して下さ い)」と具体的かつ適確な指示を含む臨床に則した内容 へ修正された。また，小児科からは，「初期症状」に記 載された主観的な症状に加え, 家族の方が気づくような 客観的な症状も記載してほしいという要望があり, 小児 科で使用する薬の小児科用の「初期症状」には，「息を するとき喉がヒューヒュー鳴る」等客観的な症状も加 え, 他科の「初期症状」とは別に作成して登録した。

このように,「薬の働き」と「初期症状」の項目につ いては, 診療科別の登録を可能としたことで, 各科の医 師の意見を『くすりのせつめい』の内容に個別に反映さ せることができた。 また, 全診療科の医師の合意を得た ことで，医師と連携のとれた薬剤情報提供が可能となっ た。

\section{3 ) 非医療関係者の意見による修正}

非医療関係者 15 人から協力が得られた。その内訳は, 男性 5 人, 女性 10 人, $20 \sim 70$ 歳代（平均年齢 $48 \pm 16.3$ 歳）と幅広い年齢層から意見を聞くことができた.

非医療関係者からわかりにくいと指摘された件数は 108件であり, 重複を除く81件中71件について修正し た。これを項目別にみると，「薬の働き」が最も多く， 次いで「使用上の注意」ならびに「初期症状」の順に多 くの修正が必要であった（表 1 ）.71件の意見を基に修 正した品目数は500品目 $(50.2 \%)$ であり, その修正例 を表 2 に示す。

このように医師や非医療関係者の意見により修正を加 えて作成した『くすりのせつめい』の例を図 1 に示す.

\section{2. 『くすりのせつめい』に関するアンケート調査}

アンケート実施期間中に院内処方せんが出された外来 患者は 445 人で, そのうち 300 人 $(67.4 \%)$ から回答が得 られ，全科からの回答が含まれていた．院内処方せんが 出された患者のうち薬剂情報を提供したのは427人で あった。回答したのは，男性 125 人，女性 168 人，不明 7 
なりましたか？」の質問に対して，64\%の患者が「安心

人，平均年齢 $53 \pm 19.1$ 歳（不明 6 人）であった。以下, 質問事項順に結果をまとめた。

「医師から薬についての説明をうけておられます か?」の質問に対して，「納得のいく説明を受けてい る」は $46 \%$ と半数以下であった（図 2 ).

「『くすりのせつめい』を読まれましたか？」の質問に 対して，93\%の患者が「全て読んだ」「関心のあるとこ ろだけ読んだ」と回答しており 9 割以上の患者に読まれ ていた (図 3 ).

「『くすりのせつめい』は役に立ちましたか？」の質問 に対して，「役に立った」が $89 \%$ と大部分を占め，「役に 立たなかった」は $5 \%$ とわずかであった（図 4 ）.

「役に立った項目はどれですか？(複数回答)」の質問 に対する回答では，「使用上の注意」や「薬の働き」の 項目で約 $60 \%$, 「商品名, 成分名」や「副作用の初期症 状」の項目で約 $40 \%$ 患者が役に立ったと回答した（図 5 ).

「『くすりのせつめい』を読まれてどのようにお感じに

表 1. 非医療関係者の意見による項目別修正件数

\begin{tabular}{|c|c|c|}
\hline 項目 & $\begin{array}{c}\text { 修正件数 } \\
\text { (件) }\end{array}$ & $(\%)$ \\
\hline 薬の働き & 36 & $(50.7)$ \\
\hline 使用上の注意 & 12 & $(16.9)$ \\
\hline 副作用の初期症状 & 11 & $(15.5)$ \\
\hline 剂形, 〈すりの色, 識別コードなど & 4 & $(5.6)$ \\
\hline 一般的注意 & 4 & $(5.6)$ \\
\hline 保管上の注意 & 1 & (1.4) \\
\hline その他 & 3 & $(4.2)$ \\
\hline 計 & 71 & $(100.0)$ \\
\hline
\end{tabular}

して薬を飲めるようになった」と回答しており，「少し 心配になった」は 3 \%とわずかであった（図6）。

「ふだんから，薬はきちんと飲んで（使って）おられ ますか?」の質問に対して，89\%の患者が「きちんと飲 んでいる」と回答した（図７）．「それは『くすりのせつ めい』を読まれて変わりましたか?」の質問に対して は，『くすりのせつめい』を読んだ後，43\%の患者がさ らに「きちんと飲むようになった」と回答していた（図 8 ).

非医療関係者の意見による項目別修正件数（表 1）で わかりにくいと指摘を受けた割合が一番高かった項目で

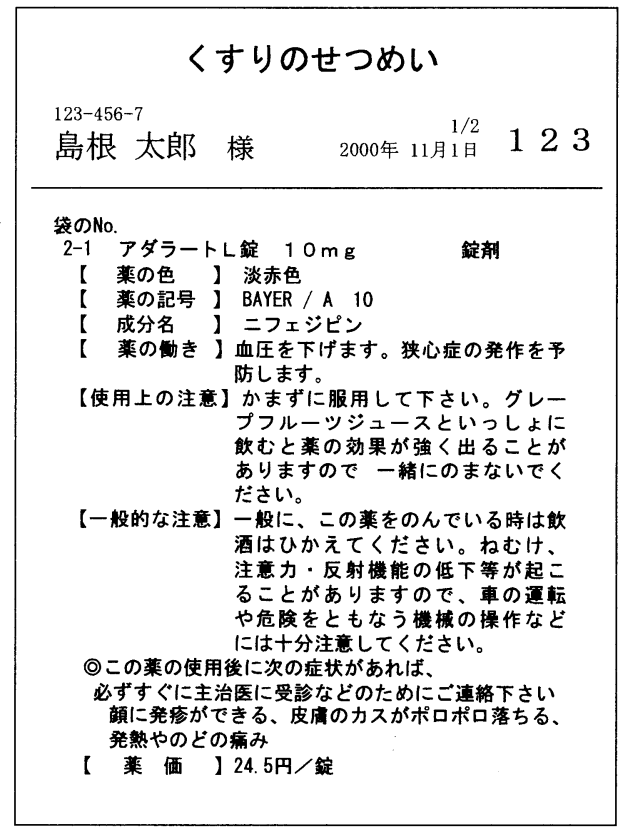

図 1.『くすりのせつめい』の一例

表 2. 非医療関係者の意見による修正例

\begin{tabular}{|c|c|c|c|}
\hline 原 & 案 & 意 見 & 提 供 情 報 \\
\hline \multicolumn{2}{|c|}{$\begin{array}{l}\text { 空腹時に服用すると } \\
\text { 吸収が低下します }\end{array}$} & $\begin{array}{l}\text { 「吸収が低下します」がわか } \\
\text { りにくい }\end{array}$ & 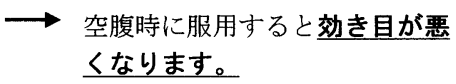 \\
\hline \multicolumn{2}{|c|}{$\begin{array}{l}\text { 服用後短時間のうち } \\
\text { に顔が赤く熱くなる }\end{array}$} & $\begin{array}{l}\text { 「短時間」は具体的な数字で } \\
\text { 表現できないか? }\end{array}$ & 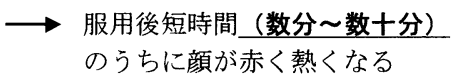 \\
\hline \multicolumn{2}{|c|}{ そけい部や足の痛み } & 「そけい部」がわかりにくい & 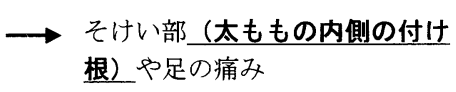 \\
\hline \multicolumn{2}{|c|}{$\begin{array}{l}\text { 痛風発作を予防· } \\
\text { 絈解する薬です }\end{array}$} & 「緩解する」がわかりにくい & $\begin{aligned} \longrightarrow & \begin{array}{l}\text { 痛風発作を予防したり、やわら } \\
\text { げたりする薬です。 }\end{array}\end{aligned}$ \\
\hline
\end{tabular}




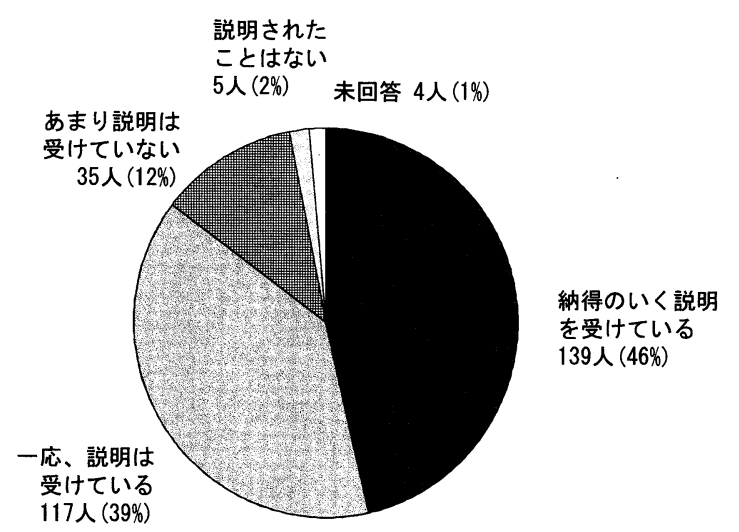

図 2. 医師から薬についての説明を受けておられま すか? $(n=300)$

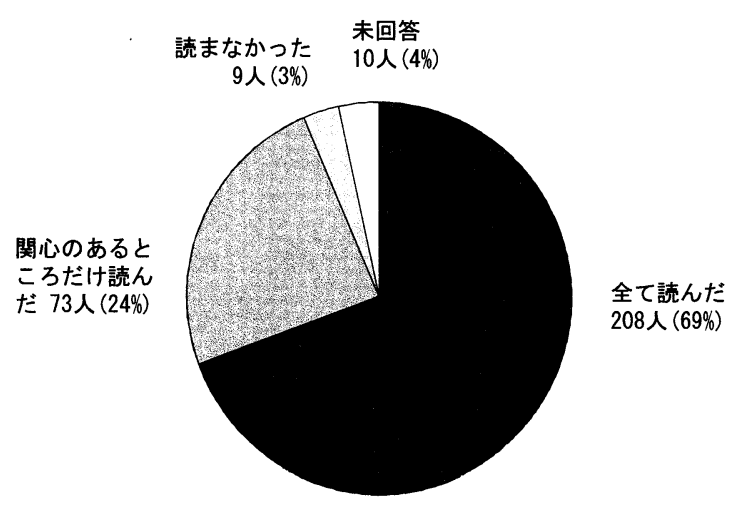

図 3.『くすりのせつめい』を読まれましたか？ $(\mathrm{n}=300)$

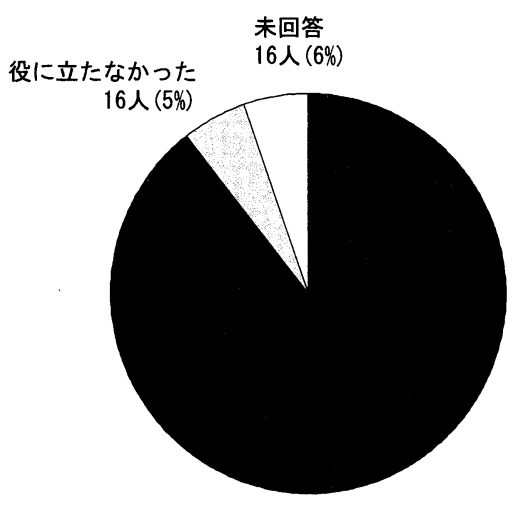

役に立った 268人 (89\%)

図 4.『くすりのせつめい』は役に立ちました か? $(\mathrm{n}=300)$

ある「薬の働き」の内容・言葉使い・理解度に対する回 答を図 9 に示す。内容については，51\%の患者が「ちょ うどよい」と回答し，「もっと簡単に」は $6 \%$ とわずか であった。また，言葉使いは「わかりやすい」と「ちょ うどよい」の合計が全体の74\%を占めていた．理解度に ついても，89\%の患者が「良くわかった」あるいは「あ
る程度わかった」と回答した。

同じく修正の指摘を受けた項目である「副作用の初期 症状」の内容・言葉使い・理解度に対する回答を図10に 示す.内容については，51\%の患者が「ちょうどよい」 と回答したが，もっと詳しい内容の要望が $24 \%$ \%った. また言葉使いは，「わかりやすい」と「ちょうどよい」

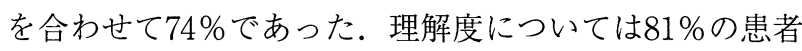
が,「良くわかった」あるいは「ある程度わかった」と 回答していた.

\section{考察}

薬剤情報提供は極めて重要であるが，提供した情報が 患者に理解されなければその意義は極めて低いものとな る。「服薬指導用語に対する患者および中学生の理解 度」によると, 日常的な意味と薬学としての専門的な意 味に差がある場合や，文字から読み取れる意味と実際の 意味に差がある場合に不正解が多いと報告されてい る8).われわれも薬剤師がわかると判断した用語でも患 者により理解されないこともありうると考え, 非医療関 係者の意見を取り入れて『くすりのせつめい』を作成 し，さらにアンケートにより実際の患者の意識調査を 行った。

「医師から薬についての説明をうけておられます か?」の質問に対して，納得のいく説明を受けている患 者は過半数にみたず，薬剤情報提供の必要性が強く示唆 された（図 2 ). 図には示していないが，納得のいく説 明を受けていると回答した患者の $94 \%$ はくすりのせつ めい』が「役に立った」と回答していることから，医師 からの説明とは別に文書による薬剤情報提供の必要性が 示唆された。

「役に立った項目はどれですか？」の質問（図 5 ）に 対し，役に立った上位 4 項目のうち「薬の働き」，「商品 名, 成分名」, 「副作用の初期症状」は, 厚生省の「医薬 品等の適正使用のための情報提供ガイドライン評価に関 する研究」の総括研究報告書 $\left.{ }^{9}\right)$ に報告されている患者が 知りたい情報の上位項目とほほ一致していた，今後，患 者のニーズを考慮し，さらに充実した薬剤情報提供を進 めていく必要があると考える．逆に「薬価」は $13.7 \%$ と 役に立ったと回答した割合が 1 番低く，患者のコスト意 識は低いことが判明した。答申書(4)に「今後の保険制度 を考慮すると患者にコスト意識をもってもらうととも に，われわれ薬剤師もそれを上回るコスト意識をもって 患者に対応すべきである」と記載されているように，薬 価の情報を提供することにより，薬剤師・患者ともにコ ス卜意識をもつよう啓蒙していく必要があると考える.

「ふだんから，薬はきちんと飲んで（使って）おられ 


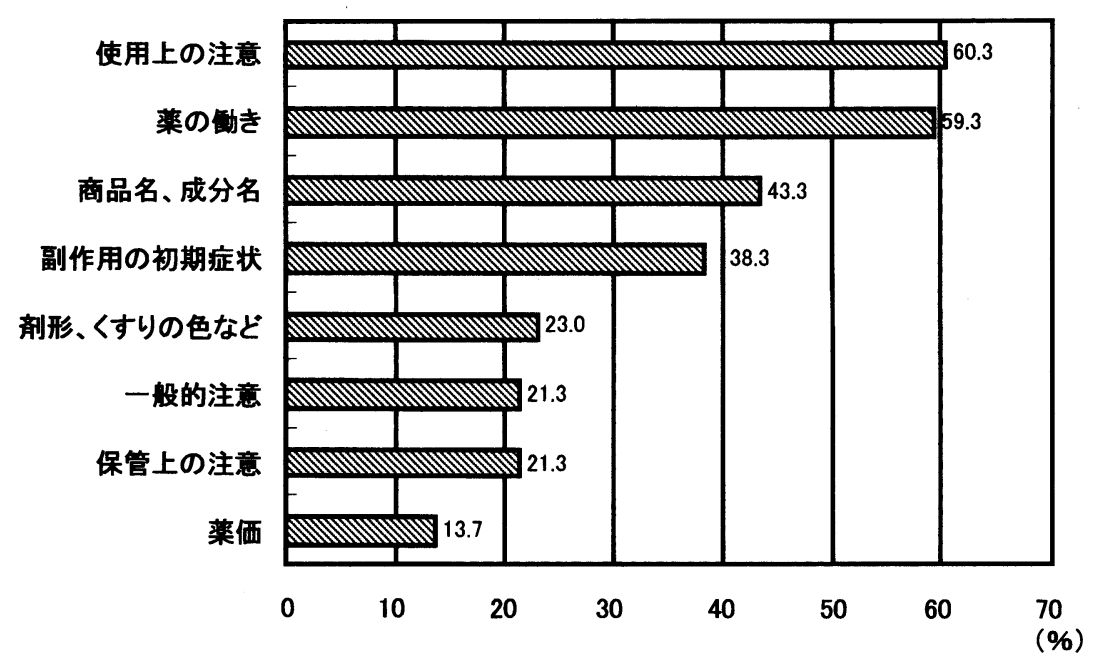

「役に立った」と回答した割合

図 5. 役に立った項目はどれですか? (複数回答, $\mathrm{n}=300$ )

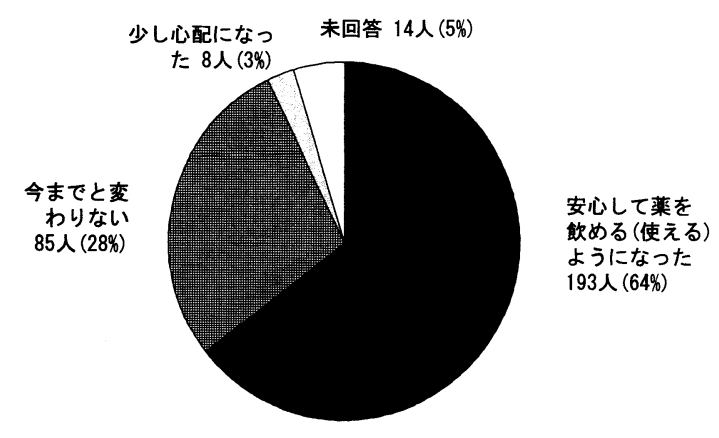

図 6.『くすりのせつめい』を読まれてどのように お感じになりましたか? $(\mathrm{n}=300)$

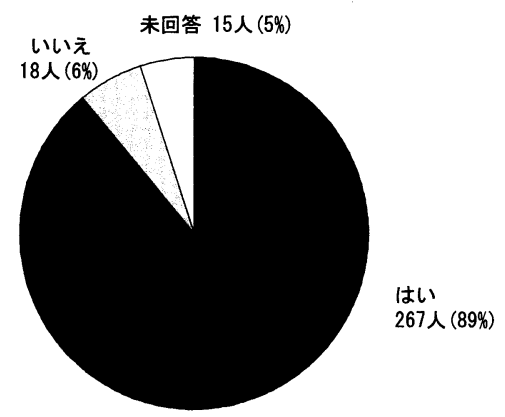

図 7. ふだんから，薬はきちんと飲んで（使って） おられますか? $(\mathrm{n}=300)$

ますか?」の質問に対して，「はい」と回答した患者は 267人（89\%）であった（図 7 ).「それは『くすりのせ つめい』を読まれて変わりましたか?」の質問に対し 「きちんと飲むようになった」と回答した患者は 130 人 (43\%) であった（図 8).「きちんと飲むようになっ

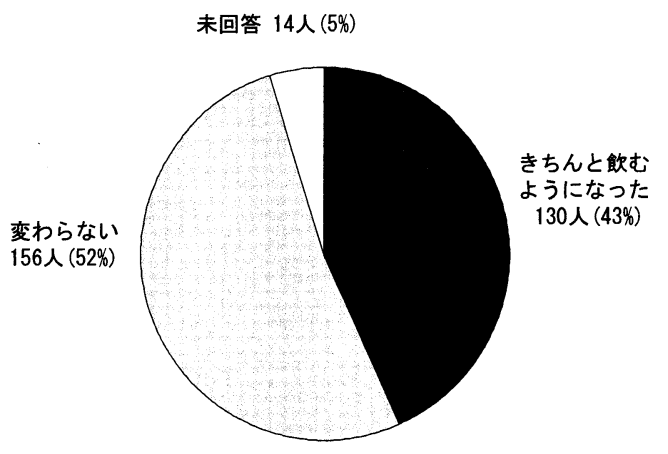

図 8.それは『くすりのせつめい』を読まれて変わ りましたか? $(\mathrm{n}=300)$

た」と回答したのは，先の質問で「はい」と回答した 267人のうち 117 人，「いいえ」と回答した 18 人のうち 6 人，未回答であった 15 人のうち 7 人であった.『くすり のせつめい』は普段からコンプライアンスが良好とみな される患者に対しても, さらに適正な服薬の徹底を促し たと考えられる。

一方，『くすりのせつめい』を読んで「安心して薬を 飲めるようになった」と回答したのは64\%にすぎず, 「今までと変わらない」と回答した $28 \%$ の患者がさらに 安心して服薬できるよう, 今後はお薬相談空口による個 別の対応などが必要であると考える。「少し心配になっ た」と回答した患者がわずかではあるがいた（図 6 ). 図には示していないがこれらはふだんから「きちんと薬 を飲んでいる」患者であった。「少し心配になった」と 回答した 8 人の患者のうち 2 人は『くすりのせつめい』 を読んだ後も「きちんと飲むようになった」と回答し， 


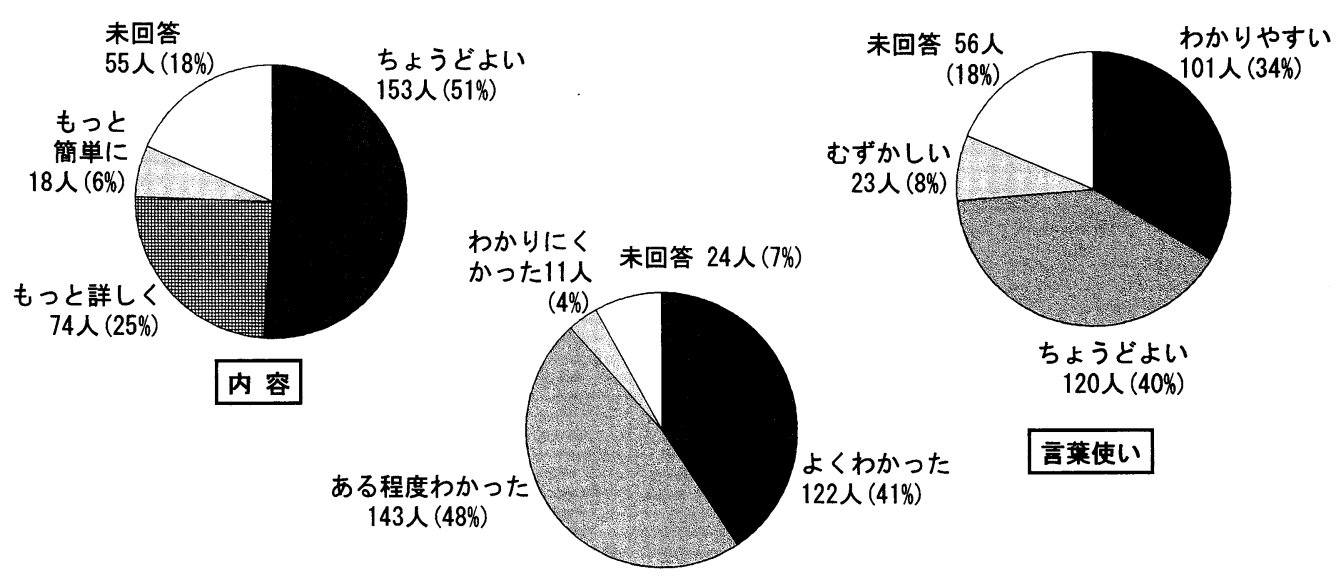

理解度

図 9.「薬の働き」について $(\mathrm{n}=300)$

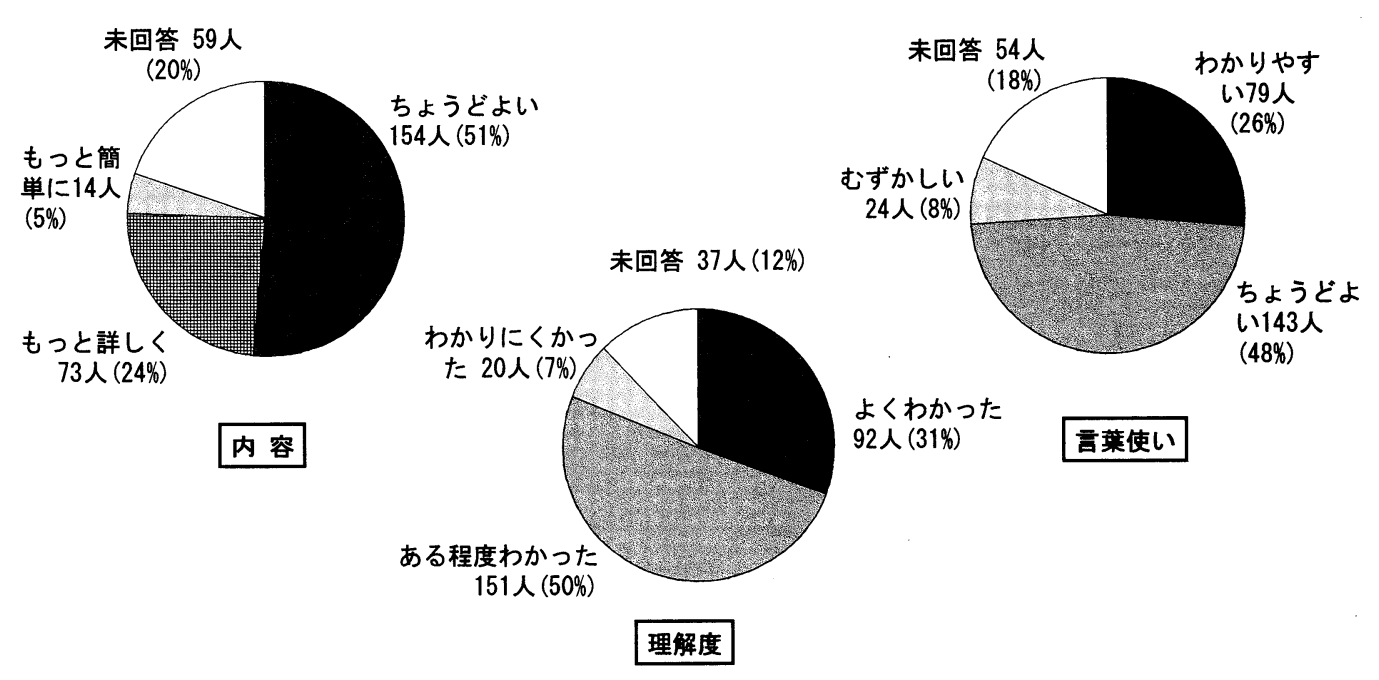

図 10.「副作用の初期症状」について $(n=300)$

残りの 6 人も「変わらない」と回答しており, 回答数は 少ないもののコンプライアンスの悪化は認められなかっ た。山崎らは副作用に対する不安を抱えながらも「くす りのしおり」を読むことにより，正しい服薬が促進され ると考えられる ${ }^{10)}$ と報告している。室原らはある程度 詳細な内容をもつ説明書は, 患者に受け入れられ，コン プライアンスを改善し有用であると考えられる ${ }^{11)}$ と報告 している。これらの報告と同様に今回の結果からも, 副 作用についての薬剤情報提供がコンプライアンスの悪化 には必ずしも結びついていないと考えられる。コンプラ イアンスが悪化しなかった理由として, 本院の『くすり のせつめい』の副作用情報は副作用用語ではなく「初期 症状」を平易な表現で示していること，この発現頻度は 必ずしも高いものではないことを補足して記載している
ことが考えられる.さらに医師の意見を取り入れ，あら かじめ了承を得た内容を提供したことも，1つの要因と なっている可能性が考えられる。

「薬の働き」および「副作用の初期症状」についての 質問に対して，言葉使いに関して高い評価が得られた。 非医療関係者の意見を取り入れ，表現方法をできるだけ 具体化したり，平易な言葉使いに修正したことにより， これらの情報が患者に十分受入れられた結果であると考 える. 理解度についてはさらに高い評価を得ているが， 「副作用の初期症状」は「薬の働き」に比べやや評価が 低かった。この原因として, 初期症状の記載順が系統化 されていないためではないかと考えられる，例えば，副 作用を部位別に分けて記載するなどの工夫が今後必要で あると思われる。また，この項目には重大な副作用を回 


\section{4}

避するために必要な情報を記述することにしたため，そ の記入が必要な薬剤では最高で 27 語，平均でも 7 語と文 字数が多くなった。しかし，さらに詳細な副作用の説明 を希望する患者が意外に多かった，厚生省の総括研究報 告書 ${ }^{9)}$ や山崎ら ${ }^{10)}$ の報告と同様に，患者は詳細に説明 された副作用も有用な情報と考えていると思われる. 『くすりのせつめい』を患者が実際に見て服用している 薬剂の副作用に気付き，主治医に相談した結果，該当薬 が中止となった事例が本情報を提供開始後月平均で 1 例 とわずかではあるが，医師より報告されている，薬剤に よる副作用の防止は医師等と協力して薬剤師が担うべき 大きな役割でもあり，そのための薬剤情報提供は今後ま すます重要になると考えられる.

今回の結果において，本院で作成した『くすりのせつ めい』の有用性や理解度等に関して低い評価を示した患 者もわずかながら存在することから，薬剤管理指導業務 等を通じてより多くの患者からの直接の意見を随時取り 入れることにより，外来患者に対してもさらにわかりや すい文書になるよう努力している，今後も，患者の意見 を反映させた薬剤情報提供を行うことにより，各患者に おいて医薬品の適正使用がさらに推進されるよう努め, 薬物療法の向上を計りたいと考える.

\section{引用文献}

1）本田義輝，安成琴子，緒方正輝，堤尚子，中山貴 夫, 高野佐知子, 中野眞沉, 熊本大学医学部附属 病院における外来患者への薬剤情報提供, 病院薬 学, 24, 576-583(1998).
2）杉山正，柴山朋子，高木直子, 安田浩二, 安田公 夫，片桐義博，処方オーダリングシステムと連動 した薬剤情報提供システム, 病院薬学, 24, 292300(1998).

3）石塚良子，尾崎淳子，中村暢彦，若杉博子，二見 高弘，石津雅弘，乾賢一，外来患者への薬剤情報 提供 (1)「おくすり説明書」の利用, 日病薬誌, 34, 1033-1038 (1998).

4）日本病院薬剤師会薬剤業務委員会，患者等への薬 剂情報の進め方 (答申書)，日病薬誌，33，192195(1997).

5）日本病院薬剂師会編, “重大な副作用回避のための 服薬指導情報集 I”，薬業時報社，東京，1997。

6）日本病院薬剂師会編，“重大な副作用回避のための 服薬指導情報集 II”，薬業時報社，東京， 1998 .

7）日本病院薬剂師会編，“重大な副作用回避のための 服薬指導情報集 III，薬業時報社，東京，1999．

8）朝倉俊成，野崎征支郎，服薬指導用語に対する患 者および中学生の理解度, 病院薬学, 22, 497-502 (1996)

9）平成10年度厚生科学研究「医薬品等の適正使用の ための情報提供ガイドライン評価に関する研究」 総括研究報告書, 2000 .

10）山崎昌司，原田和博，黒須紀元，海老原昭夫，藤 村昭夫，「患者向け説明文書」の有用性に関する 検討，月刊薬事，38，353-365(1996).

11）室原昌洋，西端義広，細谷幸彦，稲垣正晴，大江 早江，後藤満子，恵良正道，西川正一，早川幸 宏，金美恵子，吉田真紀子，向井淳一，浜六郎， 患者用説明書に関する多施設共同研究一外来患者 用薬剂説明書を用いた服薬指導の効果一, 病院薬 学, 18, 236-244 (1992). 